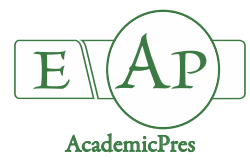

\title{
Effect of Sunny and Half-shaded Sites on the Growth of Plants and Anthocyanin Pigments Content in Leaves of Heuchera $\mathrm{L}$. 'Mysteria' and 'Peppermint Spice' Cultivars
}

\author{
Beata JANOWSKA ${ }^{1 *}$, Piotr K. CZUCHAJ ${ }^{1}$, Jan KUBIŚ2, \\ Magdalena RYBUS-ZAJĄC ${ }^{2}$, Daniela KOKOCIŃSKA² \\ IPoznań University of Life Sciences, Faculty of Horticulture and Landscape Architecture, Department of Ornamental Plants, ul. Dąbrowskiego \\ 159,60-594Poznań,Poland; beata.janowska@up.poznan.pl( ${ }^{*}$ corresponding author);piotr.czuchaj@up.poznan.pl \\ ${ }^{2}$ Poznań University of Life Sciences, Faculty of Horticulture and Landscape Architecture,, Department of Plant Physiology, ul. Wotyniska 35, 60- \\ 637 Poznań,Poland;jan.kubis@up.poznan.pl;magdalena.rybuszajac@up.poznan.pl; daniela.karasiak@gmail.com
}

\begin{abstract}
Two cultivars of Heuchera L. - 'Mysteria' and 'Peppermint Spice' were grown in a collection at a sunny site and a slightly shaded one. The access of sunlight was limited by shade nets, which were stretched on wooden scaffolding over the plants. The dynamics of growth of the plants in the sunny and half-shaded sites was assessed in the growth periods, in two consecutive years. After the second year, the content of anthocyanins in the leaves of different physiological maturity (young, mature and fully mature) was measured. Apart from August, during the whole growth period both cultivars formed more leaves during the first year of cultivation. Both the 'Mysteria' and 'Peppermint Spice' cultivars formed more leaves at the sunny site. The research showed that the highest content of anthocyanins in the Heuchera 'Mysteria' and 'Peppermint Spice' cultivars growing at the sunny and half-shaded sites was found in young leaves, whereas the lowest content was noted in fully mature leaves. The highest content of anthocyanins in both Heuchera cultivars was found at the initial growth period, i.e. between May and July, when the light intensity was the greatest, regardless of the place of cultivation. At the end of the growth period, the biosynthesis of anthocyanins decreased significantly. Anthocyanins accumulated in the vacuole are able to play a role as the screening pigments under intensive PAR and UV-B radiation.
\end{abstract}

Keywords: active radiation; anthocyanins; photosynthetic; UV-B radiation

\section{Introduction}

Plants are affected by solar radiation of a specific spectral composition and intensity. It influences their growth and development because it is decisive to the course and intensity of photosynthesis. Only a minimal amount of this radiation reaches plants' surface, i.e. 315-400 nm (UV), photosynthetic active radiation (PAR) of 400-700 nm and near infrared radiation (NIR) of 700-1100 nm (Skórska, 2016). Plants use some of this radiation in photochemical processes. UV radiation can be harmful due to the large amount of energy it carries. Therefore, plants undergo biochemical changes to be protected (Pilarski et al., 2012). Plants are protected from the harmful effects of UV radiation by flavonoids: flavonols and anthocyanins.

Increased accumulation of phenolic compounds is one of the main reactions to excessive UV radiation (Schreiner et al., 2012). Sinapic acid derivatives are natural 'UV screens', which absorb radiation within the range of 280$340 \mathrm{~nm}$ (Edreva, 2005). Flavonoids, which often accumulate in the cells of upper leaf epidermis, are also a specific filter limiting the penetration of UV-B radiation through the epidermis. Simultaneously, these compounds do not block PAR. Flavonoids reduce the penetration of UV-B radiation through tissues and thus, they protect the DNA and photosynthetic apparatus from damage. Apart from that, these metabolites act as antioxidants. It is proved by the fact that they can be found not only in the epidermis which is directly exposed to UV-B radiation but also in subepidermal leaf tissues (Agati and Tattini, 2010; Agati et al., 2012). Primary metabolism compounds - saccharides are precursors for the synthesis of these metabolites. All anthocyanin pigments are derivatives of the flavylium cation - 2-phenyl benzopyrylium, which occurs in the form of the carbonium or oxonium ion (Piątkowska et al., 2011). 
Anthocyanins are water-soluble plant pigments. They can be found in flowers, fruits, leaves, shoots, and less frequently in roots and wood. Their granules fill the vacuole (Troszyńska et al., 2000). Plants synthesise anthocyanins in response to stress caused by drought, pests, potassium deficiency, coldness and excessive light intensity (Tevini, 1993; Neill and Gould, 1999; Singh et al., 2017).

This study assessed the dynamics of variation in the number of leaves and content of anthocyanins in Heuchera leaves of different physiological maturity. The study was conducted on cultivars growing at sunny and half-shaded sites.

\section{Materials and Methods}

'Mysteria' and 'Peppermint Spice' - two cultivars of Heuchera L. were grown in a collection of the Department of Ornamental Plants, Poznań University of Life Sciences, Poland at a sunny site and a slightly shaded one. The plants grew in seedbeds of $1.2 \mathrm{~m}$ in width and they were spaced at $30 \times 30 \mathrm{~cm}$. They were randomly planted in three replicates. The access of sunlight was limited by shade nets, which were stretched on wooden scaffolding over the plants. The nets were removed in October due to the poor insolation. Fig. 1 shows the solar radiation intensity at both sites.

During the growth period, the plants were irrigated regularly. They were fertilised with multicomponent fertiliser (13:6:17) at an amount of $50 \mathrm{~g} \mathrm{per} \mathrm{m}^{2}$.

The dynamics of growth of the plants in the sunny and half-shaded sites was assessed in two growth periods, i.e. in 2012 and 2013. After the second year the content of anthocyanins in the leaves was measured. Samples for laboratory analyses were collected on the following days: 17 May, 14 June, 18 July, 12 September and 11 October 2013. On one day, leaves were collected from 8 plants, which were always the same. Leaves of different physiological maturity (young, mature and fully mature) were collected from a fragment of the shoot. $200 \mathrm{mg}$ sample weights were collected in three replicates to measure the content of anthocyanin pigments. The leaves differed in physiological maturity and the sites where they grew differed in the light intensity. The sample weights were ground in a mortar with $2.5 \mathrm{ml}$ of $0.5 \mathrm{M} \mathrm{HCl}$. The homogenate was centrifuged at $18.000 \mathrm{rpm}$ for 20 minutes $(25.000 \mathrm{x} \mathrm{g})$ at a temperature of $4{ }^{\circ} \mathrm{C}$. The supernatant formed above the sediment resulting from the centrifugation was collected for analyses. The content of anthocyanins was measured by means of spectrophotometry at a wavelength of $530 \mathrm{~nm}$. The extracts of the 'Mysteria' cultivar were additionally diluted with 0.5 M HCL. The content of anthocyanins was calculated using the standard curve for cyanidin chloride and it was expressed as mg per $1 \mathrm{~g}$ of fresh weight of leaves.

The results were processed statistically by means of twoway analysis of variance. Duncan's test was used. The mean values were grouped at a significance level of 0.05 .

\section{Results and Discussion}

The growth of perennials is a dynamic process. The number of leaves depends on specific morphological traits of plants and on the conditions at the place of cultivation
(Marcinkowska et al., 1998). The dynamics of variation in the number of leaves of the Heuchera L. cultivars was diversified. It depended on the cultivar and the growth site. Apart from August, during the whole growth period both cultivars formed more leaves during the first year of cultivation (Table 1). Both the 'Mysteria' and 'Peppermint Spice' cultivars formed more leaves at the sunny site.

The content of anthocyanins provides valuable information about the physiological state of plants (Steele $e t$ al., 2009). The biosynthesis of anthocyanins is genetically conditioned - it can be observed in different plant species and cultivars. Our study confirmed this observation, because the Heuchera cultivars, which had different colours of leaves, significantly differed in the content of anthocyanins, regardless of the place of cultivation.

The comparison of the content of anthocyanins in the 'Mysteria' cultivar growing at the half-shaded site showed that it depended on the physiological maturity of leaves and the sample collection time (Fig. 2A). Regardless of the sample collection time, the highest significant content of anthocyanins was found in young leaves, whereas the lowest content was noted in fully mature leaves. The highest content of anthocyanins at this site was noted in May. It was lower in June, July and September, and the lowest in October.

According to Lee et al. (2003), anthocyanins become visible in young leaves at the beginning of their growth and in ageing leaves of plants preparing for the winter rest. Many species of plants synthesise anthocyanins in response to stress caused by drought, pests, potassium deficiency, coldness and excessive light intensity (Neill and Gould, 1999). Protection from excessive light intensity is the most important function of anthocyanins in higher plants. They are located in the vacuoles of epidermal cells, where they function as a specific filter trapping sunbeams reaching plants (Steyn et al., 2002; Close and Beadle, 2003). The results of our study confirmed this thesis, because the highest content of anthocyanins in both Heuchera cultivars was found at the initial growth period, i.e. between May and July, when the light intensity was the greatest, regardless of the place of cultivation (Fig. 1). At the end of the growth period the biosynthesis of anthocyanins decreased significantly. The highest intensity of biosynthesis of anthocyanins can be observed at the beginning of growth of many plant species. In consequence, their leaves become purple. The presence of anthocyanins is temporary in this case because the pigments only provide protection from excessive solar radiation, as was proved in studies on Rosa and Ricinus communis. Young leaves of these species are initially purple, when they become more mature, their colour changes to green (Manetas et al., 2002).

The comparison of the content of anthocyanins in the 'Mysteria' cultivar growing at the sunny site showed that it depended on the physiological maturity of leaves and the sample collection time (Fig. 2B). Regardless of the sample collection time, the highest significant content of anthocyanins was found in young leaves, whereas the lowest content was noted in fully mature leaves. Regardless of the age of the leaves, the content of anthocyanins varied during the growth period. The content of anthocyanins in the leaves of different physiological maturity was increasing 
1274

significantly until July. The only exception was fully mature leaves, in which the content of anthocyanins in July was significantly lower than in June. In September and October the content of anthocyanins was significantly lower regardless of the leaf maturity.

The content of anthocyanins in the leaves of the 'Peppermint Spice' cultivar growing at the half-shaded site significantly depended on the physiological maturity of leaves and the sample collection time (Fig. 2C). From May to June the content of anthocyanins was increasing regardless of the leaf maturity. In these months the lowest significant content of anthocyanins was noted in fully mature leaves, whereas the highest content was found in young leaves. This dependence was also observed in July. However, since that month the content of anthocyanins in the leaves began to decrease significantly. In September, the highest significant content of anthocyanins was noted in young leaves. In October the content of anthocyanins was comparable regardless of the leaf age - it ranged from 29.57 to $43.30 \mu \mathrm{g} \cdot \mathrm{g}$ F.W.

The content of anthocyanins in the leaves of the 'Peppermint Spice' cultivar growing at the sunny site significantly depended on the physiological maturity of leaves and the sample collection time (Fig. 2D). Regardless of the sample collection time, the lowest significant content of anthocyanins was noted in fully mature leaves, whereas the highest content was found in young leaves. The highest significant content of anthocyanins was noted in May, regardless of the leaf age. From June to October the content of this pigment was decreasing proportionally to the leaf age.

The research showed that the highest content of anthocyanins in the Heuchera 'Mysteria' and 'Peppermint Spice' cultivars growing at the sunny and half-shaded sites was found. Plants also intensify the biosynthesis of anthocyanins in response to oxidative stress. It is a secondary stress, which accompanies the other stress conditions like intensive PAR or UV-B radiation and water stress in leaves cut off from the mother plant. Anthocyanins are probably also partially responsible for osmoregulation in plant cells (Chalker-Scott, 2002), and are able to play a role as the screening pigments under intensive solar radiation (Neill and Gould, 1999; Singh et al., 2017), accumulated in epidermis of ornamental plants leaves also improved the decorative value of ornamental plants like Heuchera cultivars.

Table 1. The dynamics of variation in the number of leaves in Heuchera 'Mysteria' and 'Peppermint Spice' according to the year of the experiment and place of cultivation

\begin{tabular}{|c|c|c|c|c|c|c|c|c|c|c|c|c|c|c|c|}
\hline \multicolumn{16}{|c|}{ 'Mysteria' } \\
\hline Month & \multicolumn{2}{|c|}{ June } & \multirow{2}{*}{ Mean } & \multicolumn{2}{|c|}{ July } & \multirow{2}{*}{ Mean } & \multicolumn{2}{|c|}{ August } & \multirow{2}{*}{ Mean } & \multicolumn{2}{|c|}{ September } & \multirow{2}{*}{ Mean } & \multicolumn{2}{|c|}{ October } & \multirow{2}{*}{ Mean } \\
\hline Site & 2012 & 2013 & & 2012 & 2013 & & 2012 & 2013 & & 2012 & 2013 & & 2012 & 2013 & \\
\hline Sunny & $34.0 \mathrm{~b}$ & $48.8 \mathrm{~d}$ & $41.4 \mathrm{~b}$ & $42.4 \mathrm{a}$ & $58.1 \mathrm{c}$ & $50.3 \mathrm{a}$ & $57.7 \mathrm{a}$ & $66.3 \mathrm{c}$ & $62.0 \mathrm{~b}$ & $125.1 \mathrm{~d}$ & $77.1 \mathrm{~b}$ & $101.2 \mathrm{~b}$ & $118.6 \mathrm{~d}$ & $89.9 \mathrm{~b}$ & $104.3 \mathrm{~b}$ \\
\hline $\begin{array}{l}\text { Half- } \\
\text { shaded }\end{array}$ & $32.3 \mathrm{a}$ & $44.6 \mathrm{c}$ & $38.5 \mathrm{a}$ & $47.4 \mathrm{ab}$ & $50.2 \mathrm{~b}$ & $48.8 \mathrm{a}$ & $56.7 \mathrm{a}$ & $59.4 \mathrm{~b}$ & $58.1 \mathrm{a}$ & $109.1 \mathrm{c}$ & $68.2 \mathrm{a}$ & $88.6 \mathrm{a}$ & $111.8 \mathrm{c}$ & $75.3 \mathrm{a}$ & $93.6 \mathrm{a}$ \\
\hline Mean & $33.2 \mathrm{a}$ & $46.7 \mathrm{~b}$ & & $44.9 \mathrm{a}$ & $54.2 \mathrm{~b}$ & & $57.2 \mathrm{a}$ & $62.8 \mathrm{~b}$ & & $117.2 \mathrm{~b}$ & $72.7 \mathrm{a}$ & & $115.2 \mathrm{~b}$ & $82.6 \mathrm{a}$ & \\
\hline \multicolumn{16}{|c|}{ 'Peppermint Spice' } \\
\hline Sunny & $43.0 \mathrm{c}$ & $44.2 \mathrm{~d}$ & $43.6 \mathrm{~b}$ & $57.4 \mathrm{~b}$ & $68.7 \mathrm{~d}$ & $63.1 \mathrm{~b}$ & $56.6 \mathrm{~b}$ & $84.3 \mathrm{c}$ & $70.5 b$ & $127.2 \mathrm{~d}$ & $100.1 \mathrm{c}$ & $113.7 \mathrm{~b}$ & $119.3 \mathrm{c}$ & $123.5 \mathrm{~d}$ & $121.4 \mathrm{~b}$ \\
\hline $\begin{array}{l}\text { Half- } \\
\text { shaded }\end{array}$ & $36.2 \mathrm{~b}$ & $27.7 \mathrm{a}$ & $32.5 \mathrm{a}$ & $59.9 \mathrm{c}$ & $36.2 \mathrm{a}$ & $48.1 \mathrm{a}$ & $49.8 \mathrm{a}$ & $49.4 \mathrm{a}$ & $49.6 \mathrm{a}$ & $85.3 \mathrm{~b}$ & $58.3 \mathrm{a}$ & $71.8 \mathrm{a}$ & $83.8 \mathrm{~b}$ & $68.4 \mathrm{a}$ & $76.1 \mathrm{a}$ \\
\hline Mean & $39.6 \mathrm{~b}$ & $36.5 \mathrm{a}$ & & $58.7 \mathrm{~b}$ & $52.4 \mathrm{a}$ & & $53.2 \mathrm{a}$ & $66.9 \mathrm{~b}$ & & $106.3 \mathrm{~b}$ & $71.8 \mathrm{a}$ & & $101.6 \mathrm{~b}$ & $95.9 \mathrm{a}$ & \\
\hline
\end{tabular}

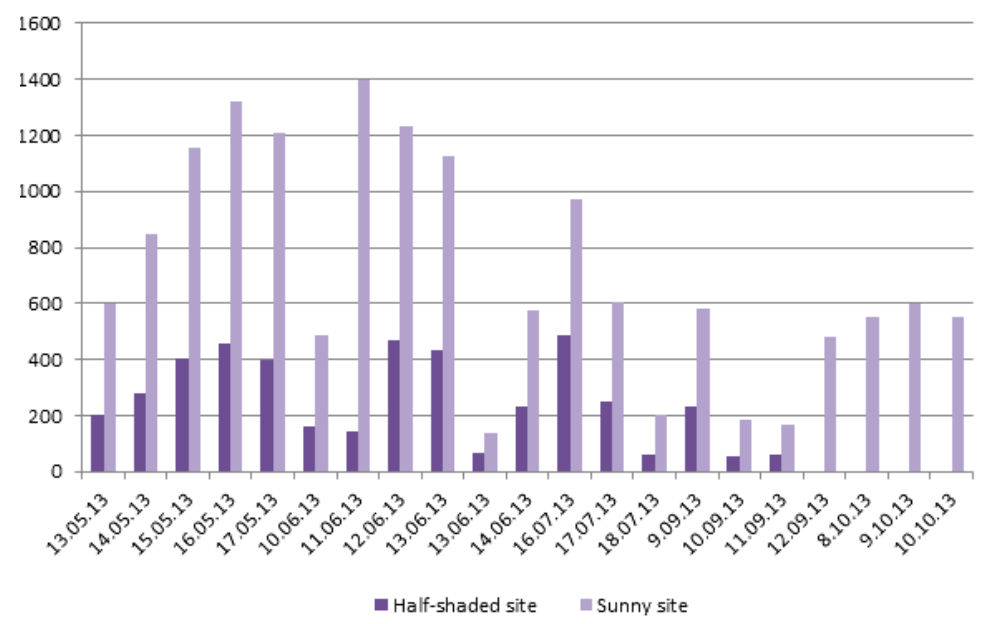

Fig. 1. The intensity of quantum irradiation $\left(\mu \mathrm{mol} \cdot \mathrm{m}^{-2} \cdot \mathrm{s}^{-1}\right)$ at the half-shaded and sunny sites 
A

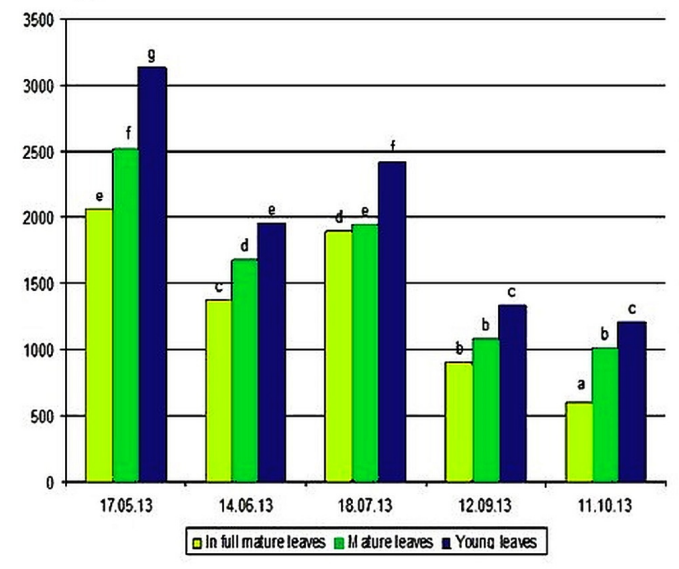

Mysteria

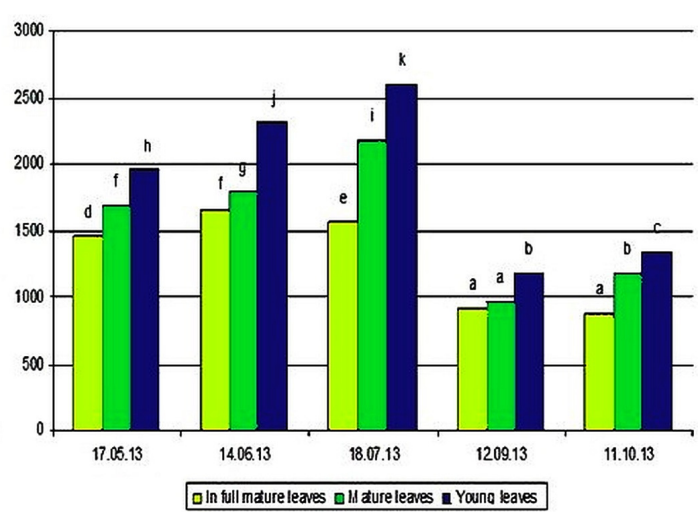

B

D
C

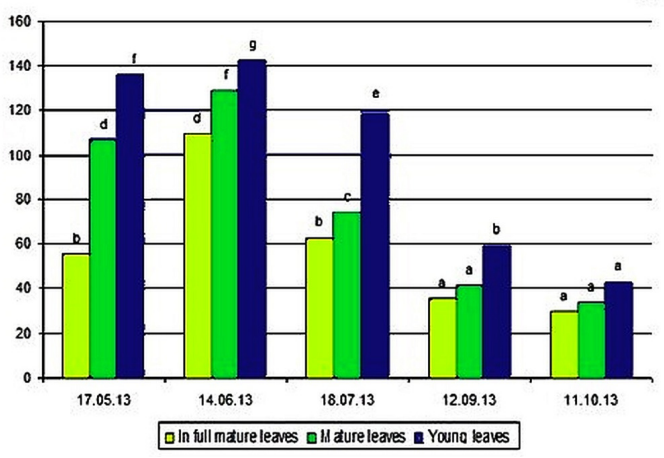

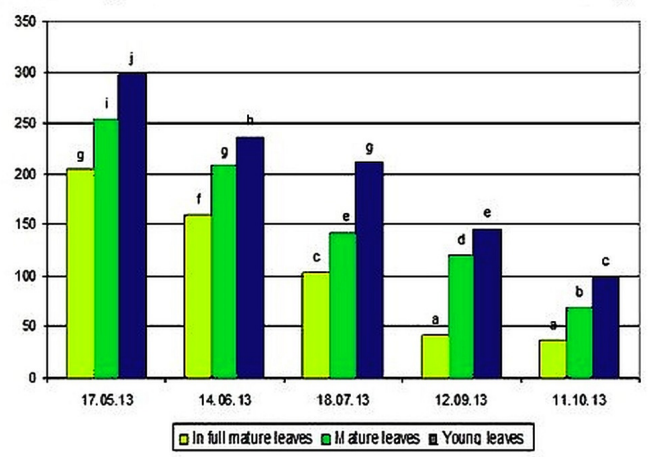

Fig. 2. Content of anthocyanins pigments ( $\mu \mathrm{g} \mathrm{g}^{-1}$ F.W.) in the leaves of Heuchera 'Mysteria' and 'Peppermint Spice'. Means followed by the same letter do not differ significantly at $\alpha=0.05$

\section{Conclusions}

Apart from August, during the whole growth period both cultivars formed more leaves during the first year of cultivation. Both the 'Mysteria' and 'Peppermint Spice' cultivars formed more leaves at the sunny site. The research showed that the highest content of anthocyanins in the Heuchera 'Mysteria' and 'Peppermint Spice' cultivars growing at the sunny and half-shaded sites was found in young leaves, whereas the lowest content was noted in fully mature leaves. The highest content of anthocyanins in both Heuchera cultivars was found at the initial growth period, i.e. between May and July, when the light intensity was the greatest, regardless of the place of cultivation. At the end of the growth period the biosynthesis of anthocyanins decreased significantly. Anthocyanins accumulated in the vacuole are able to play a role as the screening pigments under intensive PAR and UV-B radiation.

\section{Acknowledgements}

The publication was co-financed within the framework of Ministry of Science and Higher Education programme as "Regional Initiative Excellence" in years 2019-2022, Project No. 005/RID/2018/19.

\section{Conflict of Interest}

The authors declare that there are no conflicts of interest related to this article.

\section{References}

Agati G, Tattini M (2010). Multiple functional roles of flavonoids in photoprotection. New Phytologist 186(4):786-793.

Agati G, Azzarello E, Pollastri S, Tattini M (2012). Flavonoids as antioxidants in plants: Location and functional significance. Plant Science 196:67-76.

Chalker-Scott L (2002). Do anthocyanin formation as osmoregulators in leaf tissues? In: Lee DW (Ed). Anthocyanins in leaves. Advances in Botanical Research Gould, Academic Press Amsterdam pp 103.

Close DC, Beadle CL (2003). The ecophysiology of foliar anthocyanins. The Botanical Review 69(2):149-161.

Edreva AM (2005). The importance of non-photosynthetic pigments and cinnamic acid derivatives in photoprotection. Agriculture, Ecosystems and Environment 106(2-3):135-146.

Lee DW, O'Keefe J, Holbrook NM, Feild TS (2003). Pigment dynamics and autumn leaf senescence in a New England deciduous forest, eastern USA. Ecological Research 18(6):677-694. 
1276

Marcinkowska N, Szlachetka W, Prabucki A (1998). Gęstość sadzenia bylin okrywowych [Planting density of herbaceous perennials as ground covers]. Folia Universitatis Agriculturae Stetinensis Agricultura 70:6571.

Manetas Y,Drinia A, Petropoulou Y (2002). High contents of anthocyanins in young leaves are correlated with low pools of xanthophyll cycle components and low risk of photoinhibition. Photosynthetica 40(3):349-354.

Neill S, Gould KS (1999). Optical properties of leaves in relation to anthocyanin concentration and distribution. Canadian Journal of Botany 77(12):1777-1782.

Piątkowska E, Kopeć A, Leszczyńska T (2011). Antocyjany charakterystyka, występowanie i oddziaływanie na organizm czlowieka [Anthocyanins - their profile, occurrence, and impact on human organism]. Żywność Nauka Technologia Jakość 4(77):2435.

Pilarski J, Tokarz K, Kocurek M (2012). Adaptacja roślin do składu spektralnego i intensywnego promieniowania [Plant adaptation to light spectra composition and intensity]. Prace Instytutu Elektrotechniki 256:221-236.

Schreiner M, Mewis I, Huyskens-Keil S, Jansen MAK, Zrenner R, Winkler JB, O'Brien N, Krumbein A (2012). UV-B induced secondary plant metabolites - potential benefits for plant and human health. Critical Reviews in Plant Science 31(3):229-240.
Singh VP, Singh S, Prasad SM, Parihar P (2017). UV-B radiation: from environmental stressor to regulator of plant growth. Edited by: by John Wiley\&Sons Ltd. Oxford UK.

SkórskaE (2016). The impact of the solar ultraviolet radiation on the human body. Kosmos 65:657-667.

Steele MR, Gitelson AA, Rundquist DC, Merzlyak MN (2009). Nondestructive estimation of anthocyanin content in grapevine leaves. American Journal of Enology and Viticulture 60(1):87-92

Steyn WJ, Wand SJE, Holcroft DM, Jacobs G (2002). Anthocyanins in vegetative tissues: a proposed unified function in photo-protection. New Phytologist 155(3):349-361.

Tevini M (1993). Effects of enhanced UV-B radiation on terrestrial plants. In: UV-B radiation and ozone depletion: effects on humans, animals, plant, microorganisms and materials. Lewis Publishers, Boca Raton, Florida pp 125-153.

Troszyńska A, Honke J, Kozłowska H (2000). Naturalne substancje nieożywcze (NSN) pochodzenia roślinnego jako składnik żywności funkcjonalnej [Natural non-nutrients of plant origin as the components offunctional food]. Postępy Fitoterapii 2:17-22. 